\title{
On the Relations between Agent and Principal: Angove's Pty Ltd v Bailey \\ Julius A. W. Grower*
}

Key words:

Equity, Agency; Insolvency; Fiduciary Duties; Conflict of Duty and Duty; Constructive Trusts

In Angove's Pty Ltd v Bailey, the Supreme Court faced 'two important and controversial questions of commercial law': whether an agent's authority could ever be 'irrevocable', and whether the receipt of money by an imminent insolvent could ever give rise to a constructive trust of that sum. Its answers to both were heavily qualified yeses. This note supports these conclusions in principle, however, it will argue that the court's reasoning, especially in answering the second question, leaves much to be desired. In particular, it ignored the central role of fiduciary law in regulating the conduct of agents.

\section{INTRODUCTION}

In Angove's Pty Ltd v Bailey, ${ }^{1}$ the Supreme Court was presented with two questions of principle: whether an agent's authority could ever be 'irrevocable', and whether the receipt of money by an imminent insolvent could ever give rise to a constructive trust of that sum.

In the first instance, this note will lay out the facts of the case and detail the decisions that the court made. It will then examine and critique the court's reasoning. Ultimately, it will argue that while that reasoning was far from perfect, the law has been settled in a way which is largely consistent with legal theory. Having said that, this note will also take the view that, while the Supreme Court's conclusion

\footnotetext{
* Teaching Fellow, Faculty of Laws, UCL. Thanks are due to Charles Mitchell, Nick McBride, Niamh Connolly and Maria Lee. Any errors are solely my own.

${ }^{1}$ [2016] UKSC 47, [2016] 1 WLR 3179.
} 
that the agent in Angove's' authority was not 'irrevocable' may have been the correct one, it was wrong to say that no constructive trust would have arisen.

Underneath this, a broader point will be made. Angove's is one of a number of recent decisions ${ }^{2}$ which largely overlook - if not misunderstand - the central role of fiduciary law in regulating the conduct of agents. That centrality, and its practical implications, will be emphasised here.

Both of the questions posed in Angove's raise issues only sensibly determinable by reference to the fundamental nature of the relations between an agent and their principal. In order to properly understand its decisions, we must therefore first understand those relations. Unfortunately, not all legal relations can be adequately described using only the terms 'right' and 'duty': 3 they are at once too broad and too narrow. To fully describe such a relationship, other language is needed. In order to explain the structure of the law of agency, this note will therefore engage, not just with the concepts of 'rights' and 'duties', but also with the ideas of 'powers' and 'liabilities' too. ${ }^{4}$

\section{THE FACTS OF THE CASE}

Angove's was an Australian winemaker. Bailey was the administrator of an English wine merchant, D \& D Wines International Ltd ('D \& D'). Before its insolvency, D \& D was Angove's agent. This meant that, along with buying and selling Angove's wine as part of its own business, D \& D sold Angove's wine on Angove's behalf. This activity was governed by an Agency and Distribution Agreement ('ADA').

\footnotetext{
${ }^{2}$ See, for example, FHR European Ventures LLP v Cedar Capital Partners LLC [2014] UKSC 45; [2015] AC 250, and Crossco No Unlimited v Jolan Ltd [2011] EWCA Civ 1619; [2012] 2 All E.R. 754, at least in so far as it relates to the 'Pallant v Morgan equity'.

${ }^{3}$ W. Hohfeld, 'Some Fundamental Legal Conceptions as Applied in Judicial Reasoning’ (1913) 23 Yale LJ 16.

${ }^{4}$ Hohfeld also favoured the terms 'immunity', 'disability', 'liberty', and 'no-right'. These all have their place in describing other juridical relations, but not - for our purposes, at least - the relations between an agent and their principal.
} 
In the ordinary course of events - when D \& D was not itself buying Angove's wine - Angove's would send wine to Britain and D \& D would sell it for them. Those who bought the wine entered into a contract with Angove's, but they would pay the purchase price to D \& D. After deducting its commission, D \& D would account to Angove's for the balance.

In April 2012, D \& D went into administration. In July 2012, it went into liquidation. When it learned of D \& D's administration, Angove's purported to exercise a power to end their relationship: Clause 36 of the ADA provided that it was determinable by notice, with immediate effect, upon the appointment of an administrator. However, D \& D's liquidators objected to this action.

The reason for the liquidators' objection was that they knew that two buyers - Direct Wines Ltd and PLB Group Ltd - who between them had received a little under $A \$ 900,000$ worth of wine, had not yet paid D \& D for their purchases. They wanted to collect that price in, so that, after they deducted D \& D's commission, a proportion of the balance could be distributed amongst D \& D's (other) creditors. Indeed, Angove's purported termination of the ADA was designed to prevent just that from happening.

At first instance, ${ }^{5}$ Judge Pelling QC, sitting as a judge of the Chancery Division, held that D \& D's authority to collect the price had come to an end upon its receipt of Angove's notice. He said it was therefore open to Angove's to collect the money directly from the buyers.

Before the Court of Appeal, ${ }^{6}$ the liquidators argued that, notwithstanding the judge's findings as to the general efficacy of Angove's revocation, to some extent, it could not have been fully effective: D \& D had acted as agents in forming the two contracts of sale and so its authority to collect the prices due under them must have survived. How else could it recover the commission it was entitled to? Thus, they

\footnotetext{
${ }^{5}$ Angove's Pty Ltd v Bailey [2013] EWHC 215 (Ch).

${ }^{6}$ Bailey v Angove's Pty Ltd [2014] EWCA Civ 215; [2015] 1 All ER (Comm) 36.
} 
claimed to be entitled to collect the prices, to deduct D \& D's commission, and to leave Angove's to prove in the winding up for what would be a proportionate share of the balance.

Angove's disputed this, but also submitted that, even if this was correct, then the money that D \& D would receive from the buyers would be held on constructive trust for it. This would give Angove's priority in D \& D's insolvency and would mean that, through D \& D, it would be paid in full. Patten, Lewison and Sharp LLJ disagreed. They held both that D \& D's authority to collect the price was 'irrevocable', and that no such trust would arise. It was these conclusions that Angove's challenged in the Supreme Court.

\section{THE SUPREME COURT'S DECISIONS}

Lord Sumption JSC gave the only judgment. On the question of 'irrevocability', His Lordship said that an agent's authority was inherently revocable. Thus, an agent's authority 'may be revoked ... even if it [is] agreed [that it will be] irrevocable'. ${ }^{7} \mathrm{He}$ also said that this rule is subject to exceptions: when an agent 'has a relevant interest $\ldots$ in the exercise of his authority', ${ }^{8}$ their 'authority is irrevocable while [that] interest subsists'. ${ }^{9}$

An agent has such an interest where two conditions are met. First, there must actually be 'an agreement that the agent's authority shall be irrevocable'. ${ }^{10}$ Second, that authority must be given 'to secure an interest of the agent' ${ }^{11}$ whether personal or proprietary.

\footnotetext{
${ }^{7}$ n 1 above, [6].

8 ibid [7].

${ }^{9}$ ibid.

${ }^{10} \mathrm{ibid}$.

11 ibid.
} 
Applying the law to the facts, His Lordship held that D \& D's authority was not 'irrevocable'. ${ }^{12}$ Angove's purported termination was therefore totally effective. It was entitled to claim the purchase price directly from the buyers, subject to a need for it to account to the liquidators for D \& D's commission.

Like the Court of Appeal, Lord Sumption JSC came to this decision by construing the ADA. However, unlike that court, he found that the conditions of 'irrevocability' had not been met. ${ }^{13}$ Their Lordships had erred by only looking to see if D \& D's authority was actually expressed as 'irrevocable'. ${ }^{14}$ They also incorrectly held that it really was. ${ }^{15}$ Compounding this, His Lordship held that the authority was not given as security for D \& D's commission, either. ${ }^{16}$

Thus, as D \& D was not entitled to receive the money from the buyers, the Supreme Court did not need to address the second issue. The question of whether or not it would hold the money on trust if it did, did not arise. However, 'since the point [was] of some general importance', ${ }^{17}$ the court decided to answer it anyway.

So, on the admittedly false assumption that Angove's notice of termination was not effective to terminate D\&D's authority to collect the price, Lord Sumption JSC said

[W] here money is paid with the intention of transferring the entire beneficial interest to the payee, the least that must be shown in order to establish a constructive trust is (i) that that

\footnotetext{
12 ibid [17].

${ }^{13}$ ibid [16].

14 ibid [15].

15 ibid [16].

${ }^{16}$ ibid.

17 ibid. [18].
} 
intention was vitiated... or (ii) that irrespective of [that] intention ... in the eyes of equity the money has come into the wrong hands. ${ }^{18}$

A payor's intention would be vitiated when, for example, 'money was paid as a result of a fundamental mistake or pursuant to a contract which has been rescinded', ${ }^{19}$ while Equity would view money as having has come into the wrong hands when it represented 'the fruits of a fraud, theft ... or fiduciary duty against a third party. ${ }^{20}$

On the assumed facts, His Lordship held that no trust would arise. ${ }^{21}$ Here the buyers would not be paying money on the basis of a mistake. D \& D would be authorised to collect the price from them, and it is it whom they would think they had to pay. In addition, Lord Sumption emphasised the need to respect the 'important public policy [of achieving the] pro rata distribution of [an insolvent's] estate'. ${ }^{22}$ He also said he could not see a meaningful distinction between the situation where money was received 'by an agent who becomes insolvent before accounting for it' and where 'a contractor [provides] goods or services on credit' and the recipient becomes insolvent before paying. ${ }^{23}$ This appears to have inclined him against finding that the money had come into the wrong hands. For the purposes of insolvency law, the two situations could then be treated the same.

\section{LORD SUMPTION'S REASONING}

\section{On the inherency of revocability}

To establish the inherency of all authority's revocability, His Lordship reasoned:

\footnotetext{
18 ibid. [30].

${ }^{19} \mathrm{ibid}$.

${ }^{20}$ ibid.

${ }^{21}$ ibid [24].

22 ibid [25].

${ }^{23}$ ibid [26].
} 
1) 'An agent is empowered to commit his principal ... as if the principal had agreed personally.'

2) 'This is a confidential relationship importing a duty of loyalty ... on the part of the agent.'

3) ' $[\mathrm{T}] \mathrm{o}$ allow the agent to exercise his authority after it has been revoked would amount to the specific enforcement of a relationship which is by its nature not specifically enforceable' ${ }^{24}$

With respect, this is insufficient. While it is right that, as a matter of principle, an agent's authority is inherently revocable, this is not clear enough as to why.

A hint lies in His Lordship's use of the term 'empowered'. It should not be dismissed as mere verbiage. As Dowrick says, 'the essential characteristic of an agent is that he is invested with a ... power to alter his principal's legal relations with third [parties]' ${ }^{25}$ An agent's authority is therefore his power. Indeed, as a result of the existence of this power, an agent's principal is 'under a correlative liability to have his legal relations altered'. ${ }^{26}$

In Angove's, D \& D had the authority - the power - to bind Angove's into contracts of sale with third parties. It was also able to give good receipt for the price to be paid by those buyers and to deduct its commission from such sums. Reciprocally, Angove's rendered itself liable to be duty-bound to supply goods to any buyers. It was also liable to have to wait to be paid through D \& D's accounting system.

In contrast, if no agency relationship existed, D \& D could not have bound Angove's into any contracts, or given good receipt for the proceeds of its sales. This is why Pollock observed that 'by agency, [an]

\footnotetext{
${ }^{24}$ All ibid [6] (numbering added).

${ }^{25}$ F. Dowrick, 'The Relationship of Principal and Agent' (1954) 17 MLR 24, 36 (emphasis added).

${ }^{26}$ ibid.
} 
individual's legal personality is multiplied in space'. ${ }^{27}$ Thus, what Lord Sumption's first point is emphasising is that, for better or for worse, by using an agent a principal is placing himself under a profound personal vulnerability.

Now, one symptom of the existence of such a power-liability relationship as this is the imposition of a fiduciary duty (of loyalty) on the powerholder. ${ }^{28}$ Because agents attain such significant a degree of control over their principals, they are necessarily fiduciaries. ${ }^{29}$ This is why even gratuitous agents are subject to a duty of loyalty. ${ }^{30}$ It is also why, though the scope of the task which an agent is empowered to perform may be restricted, ${ }^{31}$ their duty of loyalty cannot itself be excluded without them ceasing to be any sort of agent at all. ${ }^{32}$ Lord Sumption's second proposition is therefore inarguably correct.

Having said this, the reason why the relationship between an agent and their principal is one which is inherently revocable, is not, as might be inferred from the order of His Lordship's reasons, because it is necessarily a fiduciary one. Instead, it is because of the severity of the potential for abuse that the very existence of such a relationship entails. Inherent revocability is a second and separate symptom of the potency of the agent/principal relationship.

\footnotetext{
${ }^{27}$ F. Pollock, Principles of Contract (London, Stevens \& Sons, 13th ed, 1950) 45.

${ }^{28}$ Bristol and West Building Society v Mothew [1998] Ch 1, 18. This idea is discussed by Conaglen: M. Conaglen, Fiduciary Loyalty (Oxford: Hart Publishing, 2011) 247-249.

${ }^{29}$ New Zealand Netherlands Society “Oranje” Inc. v Kuys [1973] 1 WLR 1126, 1129.

${ }^{30}$ Turnbull v Garden (1860) 20 LT 218.

${ }^{31}$ And done so in such a way as to make a breach of that duty almost impossible: see, for example, Kelly v Cooper [1993] AC 205.

${ }^{32}$ In such a case, the parties' relationship will be either purely contractual or just gratuitous. This will not mean it is completely free from legal regulation. The law of negligence may still apply via an application of the doctrine in Hedley Byrne v Heller: see, for example, Chaudhry v Prabhakar [1989] 1 WLR 29.
} 
Of course, in the usual course of events, the fact that a principal can empower an agent is beneficial to them. They can do more business than they would otherwise be able to do. However, consistently with the terms of their power, an agent might change their principal's position in a way in which is not in their best interests. In such a case, unless they can revoke their agent's authority, there is nothing a principal can do to stop this.

Thus, we can understand Lord Sumption's third point: that authority's inherent revocability follows from the same concern that animates Equity's refusal to specifically enforce contractual agency relationships. It would simply be too great an interference with a principal's personal autonomy if they were not allowed to prevent themselves from being liable to another's exercise of a power to change their legal relations. The revocation of an agent's contractually granted 'irrevocable' authority may give rise to a claim for damages,${ }^{33}$ but that threat is not comparable to the hardship which a principal could suffer if they could not curtail their liability at all.

\section{On the relevant 'exception' to that rule}

Lord Sumption's explanation of the 'relevant interest' 'exception' to the principle of revocability is also problematic. His Lordship purported to explain the existence of that 'exception' by reference to the idea that, in some cases, an agent could owe his principal a duty of divided loyalty. ${ }^{34} \mathrm{He}$ said that, if the logic of the rule against 'irrevocability' was premised on the idea that an agent owes his principal a duty of undivided loyalty, then

\footnotetext{
${ }^{33} \mathrm{n} 1$ above, [6].

${ }^{34}$ ibid.
} 
Where the parties agree that the agent is to have a personal financial interest in the performance of his agency ... his duty of loyalty is ... compromised [and so] [t]he reason for declining to enforce his right to act for the principal ... falls away. ${ }^{35}$

However, to say this is to confuse the nature of an agent's relationship with his principal qua powerholder and the nature of an agent's relationship with his principal qua fiduciary. It is also to interpret a situation outside the scope of the principle of revocability as an exception to it.

As has been said, an agent's authority is inherently revocable because of the severity of the potential abuse that the very existence of such a power-liability relationship as gives it substance entails. Thus, subject to the caveat that all agents are necessarily fiduciaries, rather than looking at the scope of an agent's fiduciary duty, His Lordship's concern should have been with the permitted scope of their powers as agents. What he should have said was that, in principle, those powers can take a number of different forms, so long as they would not necessarily render the agent unable to be subject to a fiduciary duty.

Indeed, it is for this reason that His Lordship's observation that the so-called personal interest 'exception' does not apply where an agent's only interest in the exercise of his power is in 'being able to earn his commission' ${ }^{36}$ is correct. It is standard Equitable doctrine that, so long as they are authorised, fiduciaries are entitled to make profits from the discharge of their roles. ${ }^{37}$ Having such an interest is not inconsistent with them owing their principal a duty of undivided loyalty and so not inconsistent with them being an agent.

\footnotetext{
${ }^{35} \mathrm{n} 1$ above, [8]. For 'right' in this extract, read 'power'.

${ }^{36}$ ibid [9].

${ }^{37}$ Dale v I.R.C. [1954] AC 11, 27.
} 
The problem for Lord Sumption's analysis is that there is no such thing as a duty of divided loyalty. If 'the distinguishing obligation of a fiduciary' is that he owes his principal '[an] obligation of ... singleminded loyalty', ${ }^{38}$ then someone who does not owe someone else such a duty is just not a fiduciary. This means that, in a situation such as that which Lord Sumption described as constituting an 'exception' to the rule on revocability, what is really going on is, by definition, not true agency. Because all true agents are fiduciaries, where two parties' respective powers and liabilities are such that the power-holder does not need to act loyally in the sense that a fiduciary has to, he simply cannot be an agent.

The better view is that where one party has granted another authority to sell a certain piece of land, in order that the proceeds can be used to satisfy a debt he owes the grantee, ${ }^{39}$ any agency relationship which might be thought to exist is merely 'a device' for the satisfaction of the debt. ${ }^{40} \mathrm{It}$ is 'no more than the commercial equivalent of an assignment' ${ }^{41}$

Lord Sumption disputed this by reference to a hypothetical case where an agent makes advances out of his own pocket, on behalf of his principal, in the course of trying to sell their goods. He thought that if those advances were made against the proceeds of the sale, and if the resultant debt was agreed to be secured against the agent's authority to make that sale, then there would be 'no principled reason' why the agent's authority would not be 'irrevocable', even though he was still a true agent. ${ }^{42}$ However, with respect and for reasons already given, this cannot be correct. Either an agent's principal is entitled to his undivided loyalty or else there is no agency in play at all. Without making a substantial concession to doctrinal coherence, there can be no compromise on this point. ${ }^{43}$

\footnotetext{
${ }^{38}$ Bristol and West Building Society n 28 above, 18.

${ }^{39}$ As in, for example, Gaussen v Morton (1830) 10 B \& C 731; 109 ER 622.

${ }^{40}$ P. Watts (ed), Bowstead and Reynolds on Agency (London: Sweet \& Maxwell, 20 $0^{\text {th }}$ edn, $1^{\text {st }}$ sup, 2016) Article 118, [10-007].

${ }^{41} \mathrm{n} 1$ above, [9].

42 ibid.

${ }^{43}$ Watts has made a similar point: see P. Watts, 'The Insolvency of Agents' (2017) 133 LQR 11, 12.
} 


\section{On whether the 'exception' applied}

Here we can be brief. Lord Sumption's application of the law to the facts of Angove's is unimpeachable. He noted that, because D \& D was given express authority to collect prices from buyers, it would 'have been simple enough to provide in terms that it was irrevocable', but this was not done. ${ }^{44}$ Likewise, there was nothing from which to infer that the authority was 'irrevocable'. Under the terms of the ADA, D \& D's authority to collect prices would only have survived termination 'if it constituted an "accrued right or remedy" of the agent', ${ }^{45}$ however, it was expressly described 'as a responsibility, not a right' ${ }^{46}$ Indeed, as it was always open to Angove's to collect the money from the buyers directly, ${ }^{47}$ 'responsibility' must really have been a synonym for 'power'.

In this way, Angove's arrangement with D \& D conformed to the power-liability paradigm of a true agency relationship, set out above. It therefore necessarily did not fall within the scope of the alleged 'exception', and no issue of 'irrevocability' arose. Angove's revocation of D \& D's authority was completely effective.

What is more, for this reason, Angove's can be distinguished from the earlier case of Triffit Nurseries $\mathrm{v}$ Salads Etcetera Ltd. ${ }^{48}$ The facts of Triffit were materially identical to those of Angove's, save that the claimants had not even tried to revoke their agent's authority to collect in any prices after it had ceased

\footnotetext{
${ }^{44} \mathrm{n} 1$ above, [16].

${ }^{45}$ ibid.

${ }^{46}$ ibid.

${ }^{47}$ ibid.

48 [2001] BCC 457. I am grateful to Charles Mitchell for drawing this case to my attention.
} 
trading. ${ }^{49}$ The Court of Appeal made clear that, unless covered by the terms of a termination provision, the appointment of a receiver does not automatically end an agent's authority. ${ }^{50}$

Beyond all this, Lord Sumption was also correct to say that, because it is difficult to regard D \& D's collection from the customer as being done pursuant to the exercise of 'a right', it is even harder to regard it as having a security function..$^{51}$ Collecting the price was not the only way that D \& D could recover its commission: if it was paid directly to Angove's, the commission was payable to them by Angove's. ${ }^{52}$

\section{On the possible existence of a constructive trust}

Angove's alternative argument was that, if D \& D's authority was really was 'irrevocable', then, upon its collection of the prices, a constructive trust of that money would arise. It contrasted the nature of its relationship with D \& D before and after the latter's insolvency, such that, after, a trust would come into being 'for the first time', 'upon [the payments] reaching the hands of the payee'. ${ }^{53}$

Lord Sumption JSC was right to accept the findings of the trial judge that, $a b$ initio, the relationship between Angove's and D \& D was that of agent and principal only. However, the reasons he gave for

\footnotetext{
${ }^{49}$ ibid 463-464. Indeed, as Robert Walker LJ noted, it would have been unwise for them to have done so. At 463, he observed that the claimant 'would have had the greatest possible difficulty in demanding direct payment from any of [its] customers', because, as the agent bundled the claimant's goods together with those of a number of other sellers in order to increase their marketability, 'it would not normally have any records showing that its produce had been sold to a particular customer at a particular price'. The 'course of dealing' between the agent and its principal 'made it a practical necessity' that these trade debts should be collected by the former.

50 ibid 464.

${ }^{51} \mathrm{n} 1$ above, [16].

52 ibid.

${ }^{53}$ ibid. [25].
} 
doing so cannot be accepted. The issue is not resolved by asking whether a trust relationship is 'appropriate' to the 'commercial' context 'in which the parties find themselves', or whether what was contemplated means 'that the relationship of debtor and creditor is more appropriate' ${ }^{54}$ What matters are rules of law, not judges' impressions of propriety.

English law recognises that there is more than one way to act on another's behalf. ${ }^{55}$ While a contracting agent is authorised to enter their principal into any contracts with third parties ${ }^{56}$ a collecting agent ${ }^{57}$ can give good receipt for monies due to them. ${ }^{58} \mathrm{~A}$ contracting and collecting agent can do both. In contrast, a property-acquiring agent has neither capacity. They are given money (sometimes, but not always, on trust) and are authorised to acquire new property in their own personal capacity, albeit on their principal's behalf. ${ }^{59}$ In all cases, to work out what type of agency has been created, we must examine the allocation of the benefits and burdens between the would-be agent and his principal and see what has been established.

In Angove's, the terms of the ADA did not disclose an intention to create a property-acquiring agency. Not only was there 'no express obligation to keep any money collected separate', ${ }^{60}$ but the contract also contemplated that D \& D could pay Angove's the balance of the price it collected in advance (ie before it had recovered any of it from a buyer). ${ }^{61}$ All that was intended was for D \& D to have the power to make contracts on Angove's behalf, and to give good receipt for the proceeds of those contracts when

\footnotetext{
${ }^{54}$ ibid. [19].

${ }^{55}$ See J. Grower, 'Explaining the "Pallant v Morgan Equity"” (2016) 80 Conv 434, 448-450.

${ }^{56}$ Potter v Customs \& Excise Commissioners [1985] STC 45, 51.

${ }^{57}$ As in Nelson v Rye [1996] 1 WLR 1378; [1996] 2 All ER 186.

${ }^{58}$ And, in the absence of a contract, do so in such a way as to give rise to an Equitable liability to account for its value: see Barnett v Creggy [2014] EWHC 3080 (Ch), [66].

${ }^{59}$ As in Burdick v Garrick (1870) LR 5 Ch App 233.

${ }^{60}$ n 5 above, [51].

${ }^{61}$ ibid [53].
} 
the buyer's paid. Thus it was a contracting and collecting agent. Because of this, and because the facts of the case do not reveal any possible novation of this relationship, so as to render D \& D a propertyholding agent, if a trust was to exist, it had to arise by operation of law.

Now, in Triffit, having failed to establish that it had revoked its agent's authority, the claimant sought to invoke a general principle that a contracting and collecting agent '[was] not entitled, after [it] has ceased actively to carry on [its] business, to keep for [itself] the proceeds of his principal's property' ${ }^{62}$ However, this submission was rejected. The Court of Appeal said that, if a trust was to exist, a discrete line of case law had to be invoked.

In Angove's, Angove's relied on the decision in Neste Oy v Lloyds Bank PLC. ${ }^{63}$ There a payment on account of costs, made by a ship owner to its imminently insolvent corporate agent, was found to be held on constructive trust. Bingham J reasoned that, given the situation when the payment was received

[A]ny reasonable and honest directors of that company (or the actual directors had they known of it) would ... have arranged for the repayment of that sum to the [claimant] without hesitation or delay. It would have seemed little short of sharp practice for [them] to take any benefit from the payment, and it would have seemed contrary to any ordinary notion of fairness that the general body of creditors should profit from the accident of a payment made at a time when there was bound to be a total failure of consideration. ${ }^{64}$

\footnotetext{
$62 \mathrm{n} 49$ above, 460. The term used for a contracting and collecting agent there was: 'a person whose business is to act as an agent in turning to account the property of his principal'.

${ }^{63}$ [1983] 2 Lloyd's Rep 658.

${ }^{64}$ ibid 666.
} 
Thus, 'at the time of its receipt', the agent 'could not in good conscience' retain the sum, and 'accordingly' a constructive trust was 'to be inferred' ${ }^{65}$

Unsurprisingly, the breadth of this language means there is more than one way of making sense of it. Some argue that it indicates that a trust arose because, in a general sense, it was unconscionable for the payee to retain the money. ${ }^{66}$ Fortunately, in Angove's, Lord Sumption gave short shrift to this interpretation. He was correct to say that, as a general proposition, Bingham J was 'plainly right', but only because unconscionability can be used to describe the situation whenever any particular set of facts which suffice to give rise to a constructive trust, subsist. Its use merely 'begs the question [of] what good conscience requires' ${ }^{67}$

A better view is that the trust in Neste $O y$ arose in order to prevent the agent committing a breach of fiduciary duty. ${ }^{68}$ This approach is not just doctrinally coherent, but can also account for the result in that case, and apply to the facts of Angove's. Indeed, Lord Sumption JSC did say that a constructive trust could arise when it represented 'the fruits of a breach of ... fiduciary duty' ${ }^{69}$ however, he made no link between that proposition and the decision in Neste Oy - or his own impeding decision themselves.

What matters here is that, as fiduciaries, all agents owe their principals duties of loyalty. And whatever else they do ${ }^{70}$ duties of loyalty provide that their subjects must not place themselves in a position where

\footnotetext{
${ }^{65} \mathrm{Ibid}$.

${ }^{66}$ This was the view of the judge in Wallace v Shoa Leasing (Singapore) Pty Ltd [1999] BPIR 911.

${ }^{67} \mathrm{n} 1$ above, [28].

${ }^{68}$ I am grateful to Anna Donovan for discussing the part of fiduciary law considered hereon in with me.

${ }^{69} \mathrm{n} 1$ above, [30].

${ }^{70}$ For an interesting discussion of whether or not a separate no-unauthorised-profit rule exists, see M. Conaglen, n 28 above, $114-125$.
} 
their duty to their principal and their own interest either do or might conflict. ${ }^{71}$ Indeed, this principle has been amplified so as to proscribe a fiduciary from placing themselves in a position where their duty to one principal does or may conflict with any duty they owe to any another person, too. ${ }^{72}$ Thus, a fiduciary can serve two different masters, but only provided their roles are wholly different to one another. Stated in these terms, we can see that fiduciary duties are preclusionary duties. They look to prevent their subjects from engaging in certain types of conduct.

Unsurprisingly, the remedies made available to a principal whose fiduciary has in fact acted in breach of fiduciary duty reflect this. Thus, where, in the course of executing his role, a fiduciary enters into a transaction which generates proceeds which may be applied for his own benefit, rather than his principal's, then along with a power to ask his fiduciary to account for the value of those proceeds, a constructive trust of those proceeds will immediately arise in favour of his principal. ${ }^{73}$ Equity reinforces the principle that a fiduciary shall not be allowed to act in conflict of interest by generating entitlements which, when realised, will retrospectively prevent such an act from happening.

Indeed, this is true regardless of the fact that the fiduciary was not a trustee before his misfeasance, and that, under their terms of his engagement, he was not required to hold such proceeds on trust after his receipt of them. ${ }^{74}$ In Bhullar v Bhullar,${ }^{75}$ where two directors bought land which the company they directed might have been interested in acquiring, the Court of Appeal said that they held it on constructive trust for the company. Their duty as directors was to communicate any potentially

\footnotetext{
${ }^{71}$ n 28 above, 18.

72 ibid.

${ }^{73}$ See, for example, Phipps v Boardman [1964] 1 WLR 993. The principal then has a choice of which interest to enforce so as to retrospectively give effect to his fiduciary's loyalty.

${ }^{74}$ This is nothing extraordinary. There are many cases in which an agent - who was not initially a trustee of any of his principal's property - becomes a trustee of property falling into its hands as a result of its breach of fiduciary duty. See, generally, J. Grower, n 56 above. Pallant v Morgan [1953] Ch 43 itself concerned a property-acquiring agent.

75 [2003] EWCA Civ 424, [2003] BCC 711.
} 
commercially advantageous information to the company. ${ }^{76}$ Instead, they used it solely in their own interests.

All this is also true regardless of the fact that the fiduciary themselves may have done nothing deliberate towards creating the state of conflict, at all. As Sedley LJ once said, a fiduciary 'must not only not place himself in such a position: if, even accidentally, he finds himself in such a position he must regularise or abandon it'. ${ }^{77}$

So, it is not hard to see why, on the facts of Neste Oy, even though the money which was paid to the agent on account of costs was not paid to it in order that it be held on trust, a trust in favour of the payor was held to exist.

The agent's duty vis-à-vis its principal was to use the value of the money they were given in order to pay the principal's costs. However, its insolvency made it impossible for it to do so. Rather than trading as normal, it became duty-bound to its creditors to pool its assets - including the payment it received from its principal - so as to distribute them proportionally. Thus, even though it was not a result of any design of its own, the agent found itself, as a result of its insolvency, in a position where its duty to its principal and its duty to its creditors conflicted: viz. in breach of fiduciary duty. It could not use the money it was paid (in order to execute its role), both to so execute its role, and to pay off its creditors, yet this is exactly what was being asked of it. To invoke Bingham J's language, in the eyes of fiduciary law, it would be 'little short of sharp practice for [the agent] to take any benefit from the payment', and it would be 'contrary to any ordinary notion of fairness' that the general body their creditors 'should profit' from it. ${ }^{78}$

\footnotetext{
${ }^{76}$ ibid [41].

${ }^{77}$ In Plus Group Ltd v Pyke [2002] EWCA Civ 370, [86]; [2003] BCC 332, 350.

${ }^{78}$ n 64 above, 666 .
} 
To retrospectively prevent such a breach of fiduciary duty from occurring, a constructive trust would have arisen in favour of its principal. It would be meaningfully against good conscience for the agent to retain the sum.

\section{On whether a constructive trust did actually arise}

This means that Lord Sumption's ultimate finding - that, on the facts of Angove's, no constructive trust would exist - was wrong.

D \& D was Angove's agent and as such owed them a duty of loyalty. It was therefore precluded from exercising its power to collect in the proceeds of Angove's contracts, in such a way as to discharge a duty it owed to someone other than its principal: it could only do so in order to execute its role as Angove's agent. If, after its insolvency, D \& D exercised its power to collect the proceeds of the two outstanding contracts, it would necessarily be doing just that. Its performance of its undertaking to Angove's would be in conflict with its discharge of the duty it owed its creditors. For the reasons given above, a constructive trust would arise to retrospectively prevent that breach of fiduciary duty from occurring.

\section{CONCLUSION}

This note has argued that, though, in Angove's, the Supreme Court correctly decided the two major decisions of principle, the reasoning employed in making them was inadequate. It persistently demonstrated a limited understanding of the technical nature of the relations between an agent and their principal. In addition, though it has agreed with the disposal of the case on the first ground of appeal, this note has disagreed with the court's handling of the second ground of appeal. If D \& D's authority really was 'irrevocable', a trust would have come into existence via a routine application of fiduciary law. 
More generally, the underlying theme of this note was how poorly the court dealt with all the fiduciary law issues which arose. They were either confused or omitted. This is part of a worrying trend which we must do our best to end. 